\title{
BTLA wt Allele
}

National Cancer Institute

\section{Source}

National Cancer Institute. BTLA wt Allele. NCI Thesaurus. Code C82850.

Human BT LA wild-type allele is located in the vicinity of 3q13.2 and is approximately $36 \mathrm{~kb}$ in length. This allele, which encodes B- and T-lymphocyte attenuator protein, plays a role in mediating T-cell-derived immune responses. 